\title{
High-throughput DNA hypermethylation profiling in different ovarian epithelial cancer subtypes using universal bead array
}

\author{
MAN SOO YOON ${ }^{1}$, DONG SOO SUH ${ }^{1}, \mathrm{KYUNG}_{\mathrm{UN}} \mathrm{CHOI}^{2}$, MEE YOUNG SOL ${ }^{2}$, DONG HOON SHIN ${ }^{2}$, \\ WON YOUNG PARK ${ }^{2}$, JUNG HEE LEE ${ }^{2}$, SEONG MUK JEONG ${ }^{2}$, WOO GYEONG KIM ${ }^{2}$ and NA RI SHIN ${ }^{2}$ \\ Departments of ${ }^{1}$ Obstetrics and Gynecology, ${ }^{2}$ Pathology, Medical Research Institute, School of Medicine, \\ Pusan National University, Gyeongsangnam-do 626-770, Republic of Korea
}

Received March 17, 2010; Accepted July 1, 2010

DOI: $10.3892 /$ or_00000937

\begin{abstract}
DNA hypermethylation is common and plays a critical role in the regulation of gene expression. It is considered a major cause of carcinogenesis. High-throughput profiling method has been developed to analyze the methylation status of hundreds of pre-selected genes simultaneously. The aim of this study was to analyze promoter hypermethylation profiles of each subtype of ovarian epithelial cancer (OEC), to improve the understanding of the role of epigenetic silencing in carcinogenesis. DNA hypermethylation profiles on fresh frozen tissue samples of 5 serous, 3 mucinous, 5 endometrioid and 4 clear cell types of OEC, as well as 5 normal ovarian tissue samples as control. We used a highthroughput method for analyzing the hypermethylation status of 1,505 CpG loci selected from 871 genes simultaneously by GoldenGate Methylation Cancer Panel I (Illumina Human-6 v2 Expression BeadChip). Methylation status of seven genes was verified by methylation specific PCR (MSP). We identified 20,37, 15 and 56 hypermethylated $\mathrm{CpG}$ locations in serous, mucinous, endometrioid and clear cell type OEC compared to control. Only $6 \mathrm{CpG}$ loci were commonly hypermethylated across all subtypes of OEC. Hypermethylated loci of serous 17 (81.0\%) and endometrioid type 10 (71.4\%) were identical to that of clear cell type. However, mucinous type showed 17 peculiar loci (43.6\%) out of 39 hypermethylated loci. The unique DNA hypermethylation patterns identified in different OEC subtypes suggest that their cause may involve different epigenetic mechanisms and the Bead chip used in this study is a useful tool to analyze DNA hypermethylation.
\end{abstract}

\section{Introduction}

Ovarian cancer is the fourth leading cause of cancer death in women (1). Patients (70\%) have advanced disease (stage III

Correspondence to: Dr Kyung Un Choi, Department of Pathology, Pusan National University, Beomeo-ri, Mulgeum-eup, Yangsan-si, Gyeongsangnam-do 626-770, Republic of Korea

E-mail: kuchoi@pusan.ac.kr

Key words: hypermethylation, ovarian cancer, universal bead array or IV) upon presentation, with a 5-year survival between 15 and $20 \%$ at best with aggressive treatment. Ovarian epithelial cancer (OEC) accounts for over $90 \%$ of all cases and includes the following major histological subtypes: serous, mucinous, endometrioid and clear cell carcinomas. Cytogenetic and molecular analyses indicated that multiple genetic alterations were involved in the pathogenesis of ovarian cancer. BRCAI and $B R C A 2$ mutations are associated with increased ovarian cancer risks (2). Some studies have showed that p16 loss was associated with ovarian cancer prognosis (3). However, it remains unclear how genetic alterations lead to development and subsequent progression of ovarian cancer. Better understanding of the molecular mechanisms responsible for ovarian cancer development and progression will improve diagnosis and treatment of this disease.

DNA methylation is an epigenetic alteration that plays an important role in carcinogenesis (4). The importance of aberrant $\mathrm{CpG}$ island methylation as an alternative mechanism to inactivate tumor suppressor genes has been recognized recently. Addition of a methyl group to the cytosine residues of $\mathrm{CpG}$ dinucleotide clusters in the $5^{\prime}$ regulatory regions of genes occurs frequently in cancer cells, but seldom in nonmalignant cells. Aberrant DNA methylation occurs at the cytosines of $\mathrm{CpG}$ dinucleotides, which often exist in clusters called $\mathrm{CpG}$ islands. When methylation of these sites occurs in the promoter region of a gene, it can result in gene silencing. Silencing of functionally important genes leads to a state of high cellular proliferation. Hypermethylated $\mathrm{CpG}$ islands play a causal role in promoting cancer development and are useful molecular markers for diagnosis and prognosis.

Aberrant promoter methylation has been associated with loss of expression of a growing number of tumor-related genes in a variety of human cancers (5-8). For example, aberrant DNA methylation is a frequent epigenetic event in ovarian cancer. The importance of the role of aberrant methylation in ovarian cancer has become increasingly apparent with a growing list of genes, such as p16 (2,9), BRCA1, HICl, MLH1 and RASSF 1A (2,10-15). Methylation frequencies were higher in OEC than in borderline ovarian tumors (9). Currently, relatively little is known about the specific patterns of $\mathrm{CpG}$ island hypermethylation in different subtypes of OEC (16).

A number of recent methodological advances in the investigation of DNA methylation have enhanced the analysis of the role methylation plays in cancer. The application of DNA 
microarray technology has enabled the study of a large number of gene expression profiles from numerous tissue samples. It has provided an opportunity to classify different neoplasms based on characteristic expression patterns (17).

The GoldenGate genotyping assay was implemented on a BeadArray platform, a high throughout tool for studying methylation alterations, to determine the role of aberrant methylation in different OEC subtypes. The methylation status of 1,505 $\mathrm{CpG}$ sites in 871 genes was investigated in this study (18).

\section{Materials and methods}

Tissue and preparation of DNA samples. Normal and malignant ovarian tissue samples were obtained from the Pusan National University Hospital. Samples were stored at $-70^{\circ} \mathrm{C}$. They included samples of fresh frozen tissue of 5 serous, 3 mucinous, 5 endometrioid and 4 clear cell type OEC. Histologic subtypes were determined according to World Health Organization (WHO) standards. Five normal ovarian tissue samples were used as control. Tissue samples were obtained from patients with advanced stage OEC (stage III, 9; stage IV , 8). Staging was performed according to the FIGO staging system. The mean age of patients was 55 years, and patient age ranged from 43 to 68 years. Genomic DNA was extracted from these specimens using the QIAamp tissue kit (Qiagen). Bisulfite-c verted DNA samples were prepared using the Zymo EZ DNA Methylation kit (Zymo Research). Bisulfiteconverted DNA $(5 \mu \mathrm{l})$ was mixed with $5 \mu \mathrm{l}$ of photobiotin (MSI; Illumina) and incubated at $95^{\circ} \mathrm{C}$ for $30 \mathrm{~min}$.

Assay oligo extension and ligation. Biotinylated bisulfateconverted DNA was precipiated to remove free biotin, and subsequently dissolved biotinylated in solution (RS1; Illumina) bound to allele-specific oligonucleotides (ASOs) and locusspecific oligonucleotides (LSOs). Extension was carried out at $30^{\circ} \mathrm{C}$ overnight. Master mix (37 $\mu 1$ ) for extension and ligation (MEL; Illumina) was added to the extension products, and incubated for $15 \mathrm{~min}$ at $45^{\circ} \mathrm{C}$.

Polymerase chain reaction (PCR) amplification and PCR product preparation. After extension and ligation, beads were washed with universal buffer 1 (UB1; Illumina), resuspended in $35 \mu 1$ of elution buffer (IP1; Illumina) and heated at $95^{\circ} \mathrm{C}$ for on $1 \mathrm{~min}$ to release ligated products. The supernatant was then used in a $60-\mu 1 \mathrm{PCR}$. PCR reactions were thermocycled as follows: $10 \mathrm{~min}$ at $37^{\circ} \mathrm{C}, 3 \mathrm{~min}$ at $95^{\circ} \mathrm{C} ; 34$ cycles $\left(35 \mathrm{sec}\right.$ at $95^{\circ} \mathrm{C}, 35 \mathrm{sec}$ at $56^{\circ} \mathrm{C}, 2 \mathrm{~min}$ at $\left.72^{\circ} \mathrm{C}\right) ; 10 \mathrm{~min}$ at $72^{\circ} \mathrm{C}$ then cooled to $4^{\circ} \mathrm{C}$ for $5 \mathrm{~min}$. Three universal PCR primers (P1, P2 and P3) were respectively labeled with $\mathrm{Cy} 3, \mathrm{Cy} 5$ and biotin.

Double-stranded PCR products were immobilized on to paramagnetic particles by adding $20 \mu \mathrm{l}$ of Paramagnetic Particle B Reagent (MPB; Illumina) to each $60 \mu 1$ PCR, and incubated at room temperature for a minimum of $60 \mathrm{~min}$. Bound PCR products were washed with universal buffer 2 (UB2; Illumina) and denatured by adding $30 \mu 1$ of $0.1 \mathrm{~N}$ $\mathrm{NaOH}$. After spending $1 \mathrm{~min}$ at room temperature, released single-stranded (ss) DNAs was neutralized with $30 \mu 1$ of hybridization reagent (MH1; Illumina) and hybridized to arrays.
Array hybridization and imaging. Arrays were exposed to labeled ssDNA samples described above. Hybridization was performed under a controlled temperature gradient, from 60 to $45^{\circ} \mathrm{C}$ over $12 \mathrm{~h}$. Hybridization was held at $45^{\circ} \mathrm{C}$ until the arrays were processed. After hybridization, the arrays were rinsed twice in UB2 and once with WC1 (WC1; Illumina) at room temperature, dried for $20 \mathrm{~min}$, and then imaged at $0.8 \mu \mathrm{m}$ resolution using a BeadArray Reader. Cy3 and Cy5 dyes were excited by laser emitted at 532 and $635 \mathrm{~nm}$, respectively.

Methylation status was determinate by calculating $\beta$, defined as the ratio of fluorescent signals of both methylated allele to the sum of the fluorescent signals of both methylated and unmethylated alleles. $\beta$ value ranged from 0 in the case of completely unmethylated sites to 1 in completely methylated sites. To identify hypermethylated sites, we applied an additional filter that required a minimum difference of 0.15 in $\beta$ between malignant and control samples.

Methylation specific polymerase chain reaction (MSP). The methylation status of $7 \mathrm{CpG}$ island loci in malignant ovarian tissue samples and controls was determined by MSP. DBC1, HOXA9, SCGB3A1, SPARC, SOX1, TWIST1 and THY1 were selected for validation by MSP. DNA was extracted from 50 fresh frozen tissue samples of serous, mucinous, endometrioid, clear cell adenocarcinoma and normal ovarian tissue samples, using QIAamp DNA Micro kit (Qiagen, Hilden, Germany). Bisulfite treatment was carried out with $2 \mu \mathrm{g}$ genomic DNA using EZ DNA Methylation Cold kit (Zymo Research) according to the manufacturer's protocol. DNA samples were then purified by the Wizard DNA Cliean-Up system (Promega, Madison, WI), then treated again with $\mathrm{NaOH}$, ethanolprecipitated, and re-suspended in water.

For MSP, bisulfate-treated DNA samples were then used as PCR template with primers designed specifically for the $\mathrm{CpG}$ regions of each tested gene. Primer sequences of the methylated and unmethylated reaction were described in Table I. PCR mixture contained $2.5 \mu 1$ of $10 \mathrm{X}$ PCR buffer, $1.0 \mu 1$ of each primer, $2.5 \mu 1$ of $2.5 \mathrm{mM}$ dNTP and $0.2 \mu 1$ (1 U) hot start Taq polymerase (Takara) in a final reaction volume of $25 \mu \mathrm{l}$. PCR products were electrophoresed on $2.5 \%$ agarose gel, stained with ethium bromide, and visualized under UV illumination.

A methylation-positive DNA control was prepared in vitro using SssI methylase (New England Biolabs, Beverly, MA), which methylated every cytosine of $\mathrm{CpG}$ dinucleotide in the DNA. Ten samples of non-malignant ovarian tissue were selected as control.

\section{Results}

Global methylation profiles in OECs. We measured the methylation status of the $1,505 \mathrm{CpG}$ sites from 871 genes in different types of OECs, including serous, mucinous, endometrioid, and clear cell adenocarcinoma, and normal ovarian tissue samples as control. From this study, we obtained a list of differentially methylated markers that distinguished malignant from normal tissue samples. We identified 20, 37 , 15 and 56 hypermethylated $\mathrm{CpG}$ sites from 19, 33, 14 and 46 genes in respectively serous, mucinous, endometrioid and 
Table I. MSP primer sequence, product size and annealing temperature.

\begin{tabular}{|c|c|c|c|}
\hline Gene & Primer & $\begin{array}{l}\text { Product } \\
\text { size (bp) }\end{array}$ & $\begin{array}{c}\text { Annealing } \\
\text { temperature }\left({ }^{\circ} \mathrm{C}\right)\end{array}$ \\
\hline \multicolumn{4}{|l|}{$D B C 1$} \\
\hline Mf & 5'-TAGAGAGATGTGTAGATATAAATGG-3' & 269 & 57 \\
\hline $\mathrm{Mr}$ & 5'-CССАAАТАAАCТАAAACTAAACCATA-3' & & \\
\hline Uf & 5'-ATAGAGAGACGCGTAGATATAAACG-3' & 269 & 55 \\
\hline $\mathrm{Ur}$ & 5'-CCGAATAAACTAAAACTAAACCGTA-3' & & \\
\hline \multicolumn{4}{|c|}{ НОХА9 } \\
\hline Mf & 5'-GGTTAATGGGGGCGCGGGCGT-3' & 127 & 66 \\
\hline $\mathrm{Mr}$ & 5'-AACGCCTAACCCGCCCGACCC-3' & & \\
\hline Uf & 5'-GTATGGTTAATGGGGGTGTGGGTGT-3' & 139 & 66 \\
\hline $\mathrm{Ur}$ & 5'-CCATACCCAACACCTAACCCACCCAACCC-3' & & \\
\hline \multicolumn{4}{|c|}{$S C G B 3 A 1$} \\
\hline Mf & 5'-GGTACGGGTTTTTTACGGTTCGT-3' & 135 & 57 \\
\hline $\mathrm{Mr}$ & 5'-AАCTTCTTATACCCGATCCTC-3' & & \\
\hline Uf & 5'-GGTATGGGTTTTTTATGGTTTGT-3' & 138 & 57 \\
\hline $\mathrm{Ur}$ & 5'-CAAAACTTCTTATACCCAATCCTC-3' & & \\
\hline \multicolumn{4}{|c|}{ SPARC } \\
\hline Mf & 5'-GAGAGCGCGTTTTGTTTGTC-3' & 112 & 62 \\
\hline $\mathrm{Mr}$ & 5'-AACGACGTAAACGAAAATATCG-3' & & \\
\hline Uf & 5'-TTTTTTAGATTGTTTGGAGAGTG-3' & 132 & 62 \\
\hline $\mathrm{Ur}$ & 5'-AACTAACAACATAAACAAAAATATC-3' & & \\
\hline \multicolumn{4}{|l|}{ SOX1 } \\
\hline Mf & 5'-CGTTTTTTTTTTTTCGTTATTGGC-3' & 135 & 62 \\
\hline $\mathrm{Mr}$ & 5'-CCTACGCTCGATCCTCAACG-3' & & \\
\hline Uf & 5'-TGTTTTTTTTTTTTTGTTATTGGTG-3' & 135 & 56 \\
\hline $\mathrm{Ur}$ & 5'-ССТАСАСТСААТССТСААСАAC-3' & & \\
\hline \multicolumn{4}{|c|}{ TWIST1 } \\
\hline Mf & 5'-TTTCGGATGGGGTTGTTATC-3' & 200 & 55 \\
\hline $\mathrm{Mr}$ & 5'-AAACGACCTAACCCGAACG-3' & & \\
\hline Uf & 5'-TTTGGATGGGGTTGTTATTGT-3' & 193 & 55 \\
\hline $\mathrm{Ur}$ & 5'-ССТАACCCAAACAACCAACC-3' & & \\
\hline \multicolumn{4}{|l|}{ THY1 } \\
\hline Mf & 5'-TATTTTTATATTAATGCGGGATCGT-3' & 172 & 53 \\
\hline $\mathrm{Mr}$ & 5'-CGATTACTACACCCAACTCGAA-3' & & \\
\hline Uf & 5'-TTATTTTTATATTAATGTGGGATTGT-3' & 175 & 50 \\
\hline $\mathrm{Ur}$ & 5'-TCСААТТАСТАСАСССААСТСАAА-3' & & \\
\hline
\end{tabular}

clear cell OEC subtype, which showed higher $\beta$ values $(\geq 0.6)$ compared to that of normal ovarian tissue $(\leq 0.4)$. Only 6 $\mathrm{CpG}$ loci were commonly hypermethylated across all types of OEC; ALOX12, DAB2IP, HOXA9, HOXA11, MOS and $S P A R C$. Hypermethylated loci in serous 17 (81.0\%) and endometrioid subtypes $10(71.4 \%)$ were in common with that of clear cell subtype. However, the mucinous subtype showed 17 peculiar loci $(43.6 \%)$ out of 39 hypermethylated loci.
Selected genes fall into various classes, including tumor suppressor genes and genes involved in apoptosis, DNA repair, cell cycle, cell proliferation, differentiation, development, cell signaling, cell adhesion, transcription regulation and angiogenesis. Figs. 1 and 2 illustrate differential methylation profiles in malignant and control tissue samples, as well as specific methylation signatures obtained for individual OEC subtype. 
Validation of array results by MSP. We used MSP to confirm methylation status of the $\mathrm{CpG}$ sites of 7 genes identified by our microarray analysis; HOXA9, SPARC, SOX1, DBC1, TWIST1, SCGB3A1 and THY1 (Fig. 3).

HOXA9 and SPARC were hypermethylated in all OEC subtypes and were selected for validation. They were hypermethylated in relatively high frequencies $(22 / 40,55 \%$ and $11 / 40,27.5 \%)$. SOX1 promoter hypermethylation observed in all OECs except the endometrioid subtype on microarray was detected in 12 OEC tissue samples (30\%). Only one endometrioid adenocarcinoma tissue sample was confirmed SOX1 hypermethylation on MSP. Hypermethylated DBC1 and TWIST1 demonstrated only in mucinous adenocarcinoma were evaluated by MSP. Mucinous adenocarcinoma showed more promoter hypermethylation in two genes compared to other OEC subtypes. Promoter hypermethylation in $D B C 1$ and TWIST1 were detected in respectively $4(40 \%)$ and 2 (20\%) mucinous adenocarcinoma samples. In contrast, DBC1 hypermethylation was detected in only $13.3 \%$ (4/30) of the other OEC subtypes. Particularly, no hypermethylation was observed in other OEC subtypes for TWIST1. Four clear cell adenocarcinomas samples (40\%) showed SCGB3Al hypermethylation, and only one serous adenocarcinoma (10\%) showed SCGB3Al hypermethylation. MSP identified THY1 hypermethylation in 1 serous $(10 \%), 1$ mucinous $(10 \%)$ and 3 clear cell adenocarcinomas $(30 \%)$ tissue samples, but not in mucinous adenocarcinoma.

All of OEC tissue samples were found to have hypermethylation in one or more of the 7 genes of interest. Normal ovarian samples were unmethylated at these sites (Table II).

\section{Discussion}

This study utilized a high-throughput methodology to analyze the methylation status of hundreds of genes simultaneously, in order to elucidate methylation signatures that distinguish malignant from normal ovarian tissue samples. We used universal bead array methylation profiles (GoldenGate Methylation Cancer Panel I; Illumina Human-6 v2 Expression BeadChip) of 1,505 CpG sites from 871 genes in a panel of different types of OEC. Bead array-based platform has recently been adapted to detect DNA methylation (18). The GoldenGate Methylation assay on a bead array platform retains the high sample throughput (up to 96 samples) provided by bisulfate-based techniques, but greatly expands the number of loci (up to 1,505 CpG sites) that can be interrogated simultaneously. This method can detect changes in methylation status with only $200 \mathrm{ng}$ of genomic DNA. It does not simply measure DNA methylation qualitatively (positive vs. negative methylation), but a quantitative measure of DNA methylation levels. In this study, 22 OEC and normal ovarian tissue samples were simultaneously analyzed. We showed that $\mathrm{CpG}$ island hypermethylation is widespread in OEC genomes, and various hypermethylation patterns present in the different OEC subtypes.

Differential methylation was independently confirmed by MSP, yielding a select group of $\mathrm{CpG}$ loci that have previously been reported in OEC and other types of cancer, which may be useful as epigenetic markers for OEC. We also observed high concordance between results obtained by our microarray-
A
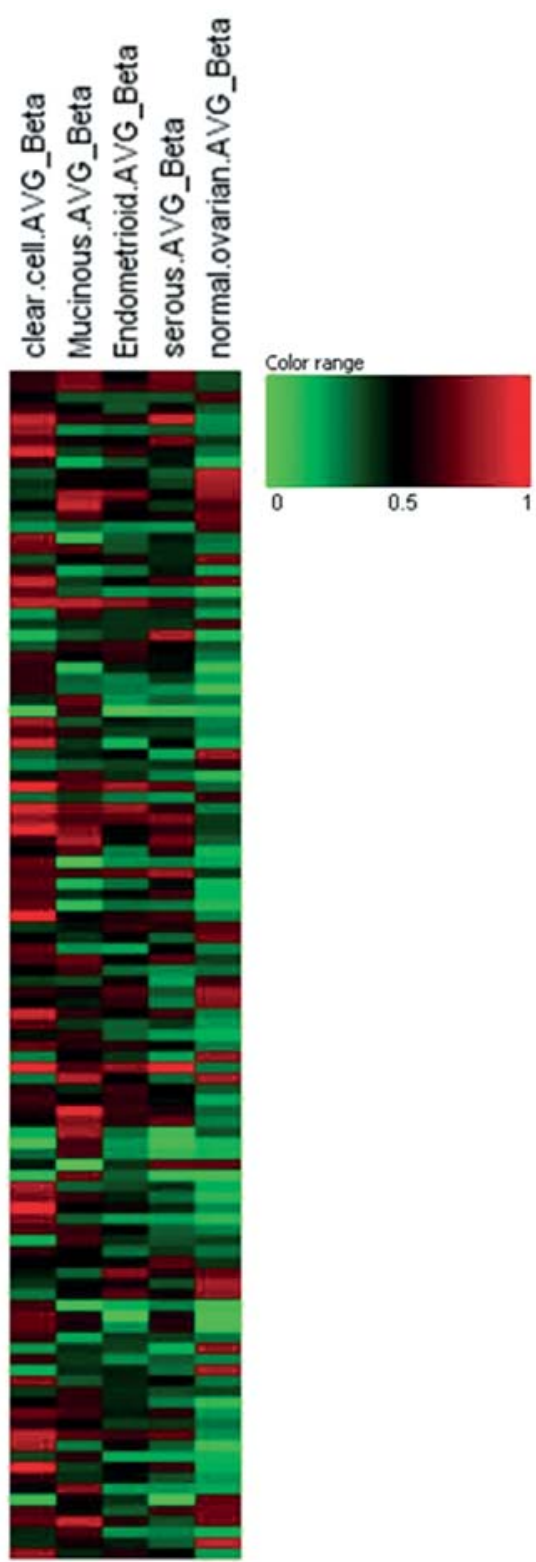

Figure 1. (A) Methylation profiling heat map feature of different types of epithelial ovarian cancers (EOCs).

based methylation analyses and that by MSP. These results led us to conclude that bead array methylation assay is appropriate for large-scale analyses of hypermethylated loci throughout the genome, whereas MSP is more sensitive in identifying a hypermethylated $\mathrm{CpG}$ locus at a time. As such, bead array methylation assay and MSP data did not completely correlate. This microarray-based technology can be considered a powerful method to simultaneously assess the methylation status of hundreds of genes in large populations.

In this study, numerous CpG loci were identified and the involving genes fall into various classes, including tumor suppressor genes and genes involved in apoptosis, DNA repair, cell cycle, cell proliferation, differentiation, development, cell signaling, cell adhesion, transcription regulation and angiogenesis. Some have previously been reported to be hypermethylated in OEC, including APC (11), HOXA9 (19), HOXAl1 (20), MYODI (21), RASSFI (22) and SCGB3A (19). 
B
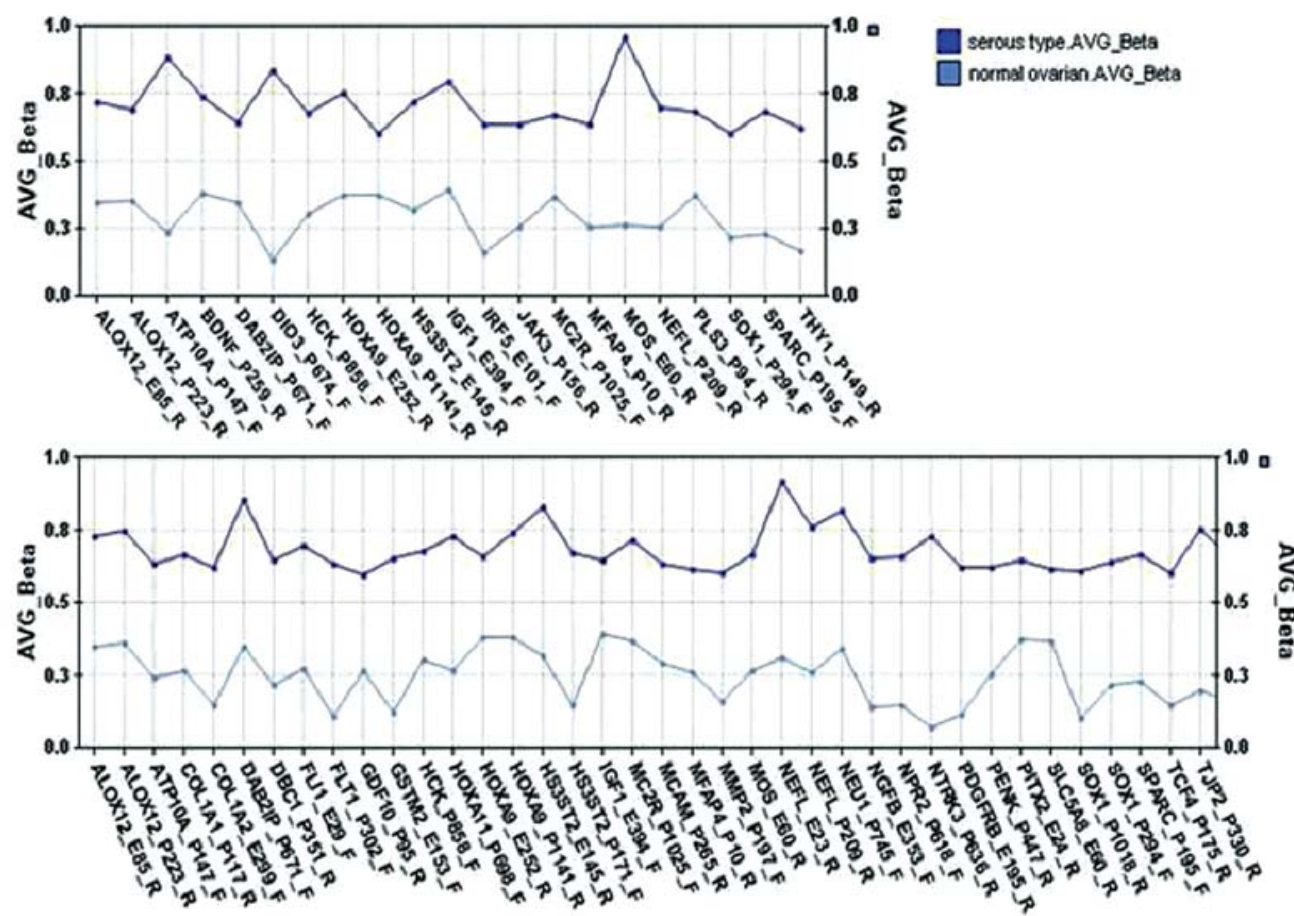

Mucinous type AVO Beta nornal ovarian AVO_Beta
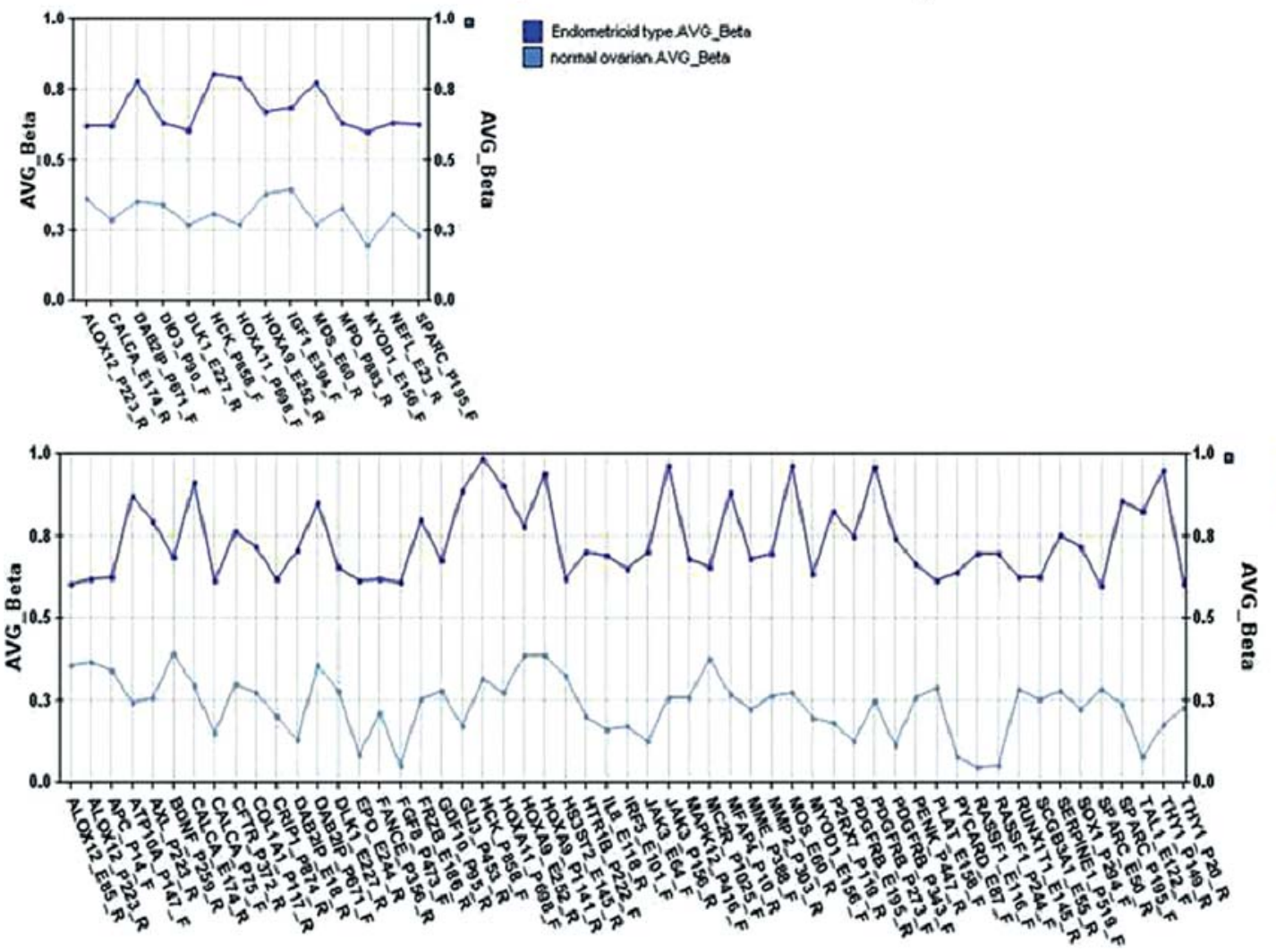

clear cel type.AVO_Beta nomal ovarisn AVG Beto

Figure 1. (B) Plot images of $\beta$ values.

Although homeobox genes have been studied extensively and their expression profiles determined in a number of human tissues, little is known about their methylation patterns, in both normal and malignant tissues. In this study, the promoter of HOXA9 was frequently hypermethylated in all types of OEC. High HOXA9 methylation frequency has been reported in all types of OEC (19). Therefore, aberrant gene expression of HOXA9 may be involved in ovarian carcinogenesis.

Secreted protein, acidic and rich in cysteine (SPARC) is a 35-kDa calcium binding glycoprotein involved in cell adhesion, motility and interactions with extracellular matrix components. SPARC expression and SPARC gene functional analysis in malignant tissues have been widely studied. Recent 


\begin{tabular}{|c|c|c|c|c|c|c|c|}
\hline Target $\mathbb{D}$ & SYMBOL & Cyto_Map & Process & $\mathrm{S}$ & $\mathrm{M}$ & $\mathrm{E}$ & $\mathrm{C}$ \\
\hline$\overline{\text { ALOX12_E85_R }}$ & ALOX12 & $17 \mathrm{p} 13.1$ & anti-apoptosis & & & & \\
\hline ALOX12_P223_R & ALOX12 & $17 \mathrm{p} 13.1$ & anti-apoptosis & & & & \\
\hline APC_P14_F & $\mathrm{APC}$ & $5 q 21-q 22$ & signal transduction & & & & \\
\hline ATP10A_P147_F & ATP10A & $15 \mathrm{q} 11.2$ & cation transport & & & & \\
\hline AXI_P223_R & AXI & $19 q 13.1$ & cell cycle & & & & \\
\hline BDNF_P259_R & BDNF & $11 \mathrm{p} 13$ & development & & & & \\
\hline CALCA_E174_R & CALCA & $11 \mathrm{p} 15.2-\mathrm{p} 15.1$ & cell signaling & & & & \\
\hline CALCA_P75_F & CALCA & $11 \mathrm{p} 15.2-\mathrm{p} 15.1$ & cell signaling & & & & \\
\hline $\begin{array}{l}\text { CFTR_P372_R } \\
\text { COL_A1 P11? B }\end{array}$ & CFTR & $7 \mathrm{q} 31.2$ & ion transport & & & & \\
\hline $\begin{array}{l}\text { COL1A1_P117_R } \\
\text { CRIP1_P874_R }\end{array}$ & $\begin{array}{l}\text { COL1A1 } \\
\text { CRIP1 }\end{array}$ & $\begin{array}{l}17 \mathrm{q} 21.33 \\
14 \mathrm{q} 32.33\end{array}$ & $\begin{array}{l}\text { development } \\
\text { cell proliferation }\end{array}$ & & & & \\
\hline DAB2IP_E18_R & $\mathrm{DAB} 2 \mathrm{P}$ & $9 \mathrm{q} 33.1-\mathrm{q} 33.3$ & signal transduction & & & & \\
\hline DAB2IP_P671_F & DAB2IP & $9 q 33.1-q 33.3$ & signal transduction & & & & \\
\hline DBC1_P351_R & $\mathrm{DBC} 1$ & $9 q 32-q 33$ & cell cycle & & & & \\
\hline DIO3_P90_F & $\mathrm{DIO} 3$ & $14 \mathrm{q} 32$ & & & & & \\
\hline DIO3_P674_F & DIO3 & $14 \mathrm{q} 32$ & & & & & \\
\hline DLK1_E227_R & DLK1 & $14 \mathrm{q} 32$ & development & & & & \\
\hline EPO_E244_R & $\mathrm{EPO}$ & $7 \mathrm{q} 22$ & cell signaling & & & & \\
\hline FANCE_P356_R & FANCE & $6 \mathrm{p} 22-\mathrm{p} 21$ & DNA repair & & & & \\
\hline FGF8_P473_F & FGF8 & $10 \mathrm{q} 24$ & cell proliferation & & & & \\
\hline FLI1_E29_F & FLI1 & $11 \mathrm{q} 24.1-\mathrm{q} 24.3$ & hemostasis & & & & \\
\hline FLT1_P302_F & FLT1 & $13 q 12$ & angiogenesis & & & & \\
\hline FR2B_E186_R & FRZB & 2qter & cell differentiation & & & & \\
\hline GDF10_P95_R & GDF10 & $10 \mathrm{q} 11.22$ & development & & & & \\
\hline GLI3_P453_R & GLI3 & $7 \mathrm{p} 13$ & regulation of transcription & & & & \\
\hline GSTM2_E153_F & GSTM2 & $1 \mathrm{p} 13.3$ & metabolism & & & & \\
\hline HCK_P858_F & $\mathrm{HCK}$ & $20 \mathrm{q} 11-\mathrm{q} 12$ & signal transduction & & & & \\
\hline HOXA11_P698_F & HOXA11 & $7 \mathrm{p} 15-\mathrm{p} 14$ & regulation of transcription & & & & \\
\hline HOXA9_E252_R & HOXA9 & $7 \mathrm{p} 15-\mathrm{p} 14$ & regulation of transcription & & & & \\
\hline HOXA9_P1141_R & HOXA9 & $7 \mathrm{p} 15-\mathrm{p} 14$ & regulation of transcription & & & & \\
\hline HS3ST2_E145_R & HS3ST2 & $16 \mathrm{p} 12$ & & & & & \\
\hline HS3ST2_P171_F & HS3ST2 & $16 \mathrm{p} 12$ & & & & & \\
\hline HTR1B_P222_F & HTR1B & $6 \mathrm{q} 13$ & cell signaling & & & & \\
\hline IGF1_E394_F & IGF1 & $12 \mathrm{q} 22-\mathrm{q} 23$ & cell proliferation & & & & \\
\hline LL8_E118_R & $\mathbb{L} 8$ & $4 q_{13}-q_{21}$ & angiogenesis & & & & \\
\hline IRF5_E101_F & IRF5 & $7 \mathrm{q} 32$ & regulation of transcription & & & & \\
\hline JAK3_E64_F & JAK3 & $19 \mathrm{p} 13.1$ & cell signaling & & & & \\
\hline JAK3_P156_R & JAK3 & $19 \mathrm{p} 13.1$ & cell signaling & & & & \\
\hline MAPK12_P416_F & MAPK12 & $22 \mathrm{q} 13.33$ & cell cycle & & & & \\
\hline MC2R_P1025_F & MC2R & $18 \mathrm{p} 11.2$ & cell signaling & & & & \\
\hline MCAM_P265_R & MCAM & $11 \mathrm{q} 23.3$ & cell adhesion & & & & \\
\hline MFAP4_P10_R & MFAP4 & $17 \mathrm{p} 11.2$ & cell adhesion & & & & \\
\hline MME_P388_F & MME & $3 \mathrm{q} 25.1-\mathrm{q} 25.2$ & cell signaling & & & & \\
\hline MMP2_P197_F & $\mathrm{MMP} 2$ & $16 \mathrm{q} 13-\mathrm{q} 21$ & extracellular matrix & & & & \\
\hline MMP2_P303_R & MMP2 & $16 q 13-q 21$ & extracellular matrix & & & & \\
\hline MOSE60_R & MOS & $8 \mathrm{q} 11$ & cell cycle & & & & \\
\hline MPO_P883_R & MPO & $17 \mathrm{q} 23.1$ & anti-apoptosis & & & & \\
\hline MYOD1_E156_F & MYOD1 & $11 \mathrm{p} 15.4$ & cell differentiation & & & & \\
\hline NEFL_E23_R & NEFL & $8 \mathrm{p} 21$ & & & & & \\
\hline NEFL_P209_R & NEFL & $8 \mathrm{p} 21$ & & & & & \\
\hline NEU1_P745_F & NEU1 & $6 \mathrm{p} 21.3$ & metabolism & & & & \\
\hline NGFB_E353_F & NGFB & $1 \mathrm{p} 13.1$ & cell signaling & & & & \\
\hline NPR2_P618_F & NPR2 & $9 \mathrm{p} 21-\mathrm{p} 12$ & signal transduction & & & & \\
\hline NTRK3_P636_R & NTRK3 & $15 \mathrm{q} 25$ & cell differentiation & & & & \\
\hline P2RX7_P119_R & $\mathrm{P} 2 \mathrm{RX} 7$ & $12 \mathrm{q} 24$ & signal transduction & & & & \\
\hline PDGFRB_E195_R & PDGFRB & $5 q 31-q 32$ & signal transduction & & & & \\
\hline PDGFRB_P273_F & PDGFRB & $5 q 31-q 32$ & signal transduction & & & & \\
\hline PDGFRB_P343_F & PDGFRB & $5 q 31-q 32$ & signal transduction & & & & \\
\hline PENK_P447_R & PENK & $8 \mathrm{q} 23-\mathrm{q} 24$ & cell signaling & & & & \\
\hline PITX2_E24_R & PITX2 & $4 \mathrm{q} 25-\mathrm{q} 27$ & development & & & & \\
\hline PLAT_E158_F & PLAT & $8 \mathrm{p} 12$ & blood coagulation & & & & \\
\hline PLS3_P94_R & PLS3 & $\mathrm{Xq} 23$ & & & & & \\
\hline PYCARD_E87_F & PYCARD & $16 \mathrm{p} 12-\mathrm{p} 11.2$ & cell cycle & & & & \\
\hline RASSF1_E116_F & RASSF1 & $3 \mathrm{p} 21.3$ & cell cycle & & & & \\
\hline RASSF1_P244_F & RASSF1 & $3 \mathrm{p} 21.3$ & cell cycle & & & & \\
\hline RUNX1T1_E145_R & RUNX1T1 & $8 \mathrm{q} 22$ & regulation of transcription & & & & \\
\hline SCGB3A1_E55_R & SCGB3A1 & 5q35-qter & cell proliferation & & & & \\
\hline SERPINE1_P519_F & SERPINE1 & $7 \mathrm{q} 21.3-\mathrm{q} 22$ & blood coagulation & & & & \\
\hline SLC5A8_E60_R & SLC5A8 & $12 \mathrm{q} 23.2$ & ion transport & & & & \\
\hline SOX1_P1018_R & SOX1 & $13 \mathrm{q} 34$ & regulation of transcription & & & & \\
\hline SOX1_P294_F & SOX1 & $13 \mathrm{q} 34$ & regulation of transcription & & & & \\
\hline SPARC_E50_R & SPARC & $5 q 31.3-q 32$ & extracellular matrix & & & & \\
\hline SPARC_P195_F & SPARC & $5 q 31.3-q 32$ & extracellular matrix & & & & \\
\hline TAL1_E122_F & TAL1 & $1 \mathrm{p} 32$ & cell differentiation & & & & \\
\hline TCF4_P175_R & TCF4 & $18 \mathrm{q} 21.1$ & regulation of transcription & & & & \\
\hline THY1_P149_R & THY1 & $11 \mathrm{q} 22.3-\mathrm{q} 23$ & angiogenesis & & & & \\
\hline THY1_P20_R & THY1 & $11 \mathrm{q} 22.3-\mathrm{q} 23$ & angiogenesis & & & & \\
\hline TJP2_P330_R & TJP2 & $9 q 13-q 21$ & & & & & \\
\hline TWIST1_P355_R & TWST1 & $7 \mathrm{p} 21.2$ & cell differentiation & & & & \\
\hline WNT10B_P993_F & $\mathrm{WNT10B}$ & 12013 & signal transduction & & & & \\
\hline
\end{tabular}

Figure 2. Methylation status of epithelial ovarian cancers (EOCs).

reports highlighted the role of this molecule as positive and negative modulators in the pathogenesis of different malig- nancies (23). In many cancers, up-regulation of SPARC has been reported in the peri-tumoral stromal cells of prostate, 


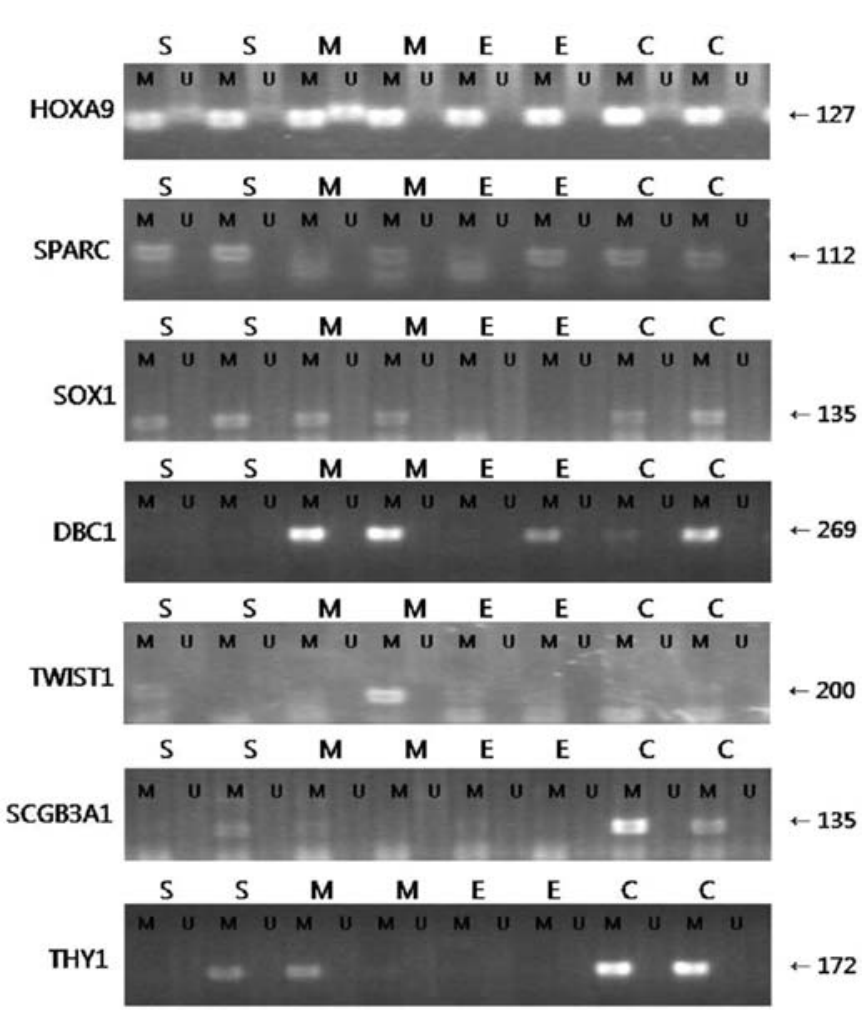

Figure 3. Representative methylation-specific polymerase chain reaction (MSP) results are shown for the 7 analyzed genes.

breast and esophageal cancer, as well as glioma $(23,24)$. However, SPARC was down-regulated in some cancers, such as colorectal carcinomas (25). Down-regulation of SPARC is related to aberrant methylation of $\mathrm{CpG}$ islands in the promoter region. Ovarian cancer cells treated with SPARC showed inhibition of cell proliferation and underwent apoptosis (26). SPARC promoter hypermethylation was found in certain OEC subtypes in this study.

SCGB3A1, also named HIN1 (high in normal-1), encodes a small secreted protein, secretoglobin $3 \mathrm{~A} 1$ and belongs to the secretoglobin family. It is reported to be a potent inhibitor of anchorage-dependent and anchorage-independent cell growth, cell migration and invasion (27). Hypermethylation- induced down-regulation of this gene has been found in several cancer types, such as breast, lung, colorectal and testicular cancer, suggestive of tumor suppressor function (28). SCGB3Al hypermethylation has been reported in mucinous and clear cell adenocarcinoma subtypes (19). This study has also demonstrated that $S C G B 3 A 1$ promoter hypermethylation occurs in OECs, suggesting that this event plays a role in the development of certain OEC subgroup.

$S O X 1$ is crucial for neuronal development. It has been reported that $S O X 1$ expression attenuates carcinogenic potential of neuronal precursors after neural stem cell transplantation (29). A recent study of DNA methylation using microarray in cervical cancer showed that $S O X 1$ was frequently hypermethylated in squamous cell carcinoma (30). We found that SOX1 hypermethylation might be associated with OEC.

THY1 is a $25-$ to $28-\mathrm{kDa}$ surface glycoprotein, which is expressed on the cytoplasmic membrane in different cell types (31). THY1 triggers a variety of cellular functions, including proliferation, lymphokine release, differentiation and apoptosis. Despite extensive investigations, the exact function and physiologic role of THY1 in the cell remains unknown (32). THY1 is associated with tumor suppression in human ovarian cancer. However, there is a lack of direct evidence in support of THYI as a candidate tumor suppressor gene in ovarian cancer (32). A recent study showed that THY1 was a good candidate tumor suppressor gene and the mechanism of THYI gene inactivation was attributed to hypermethylation in nasopharyngeal carcinoma (33). We suggest that THY1 may be a candidate marker in ovarian carcinogenesis.

The deleted in bladder cancer 1 gene $(D B C 1)$ has been identified as a potential tumor suppressor gene commonly hypermethylated or deleted in bladder cancer (34). Abnormal methylation or deletion of $D B C 1$ has also been described in other cancers, such as oral squamous cell carcinoma and nonsmall cell lung cancer $(35,36)$. Twist belongs to the basichelix-loop-helix family of transcription factors and is implicated in lineage-specific cellular differentiation and survival (37). TWIST1, an anti-apoptotic and pro-metastatic transcription factor, is overexpressed in many epithelial cancers such as breast cancer (37). Recently, human breast carcinomas have been reported to exhibit TWIST1 promoter hyper-

Table II. Summary of gene hypermethylation validated by MSP in EOCs.

\begin{tabular}{lccccccc}
\hline Type of OEC & $\begin{array}{c}\text { HOXA9 } \\
(\%)\end{array}$ & $\begin{array}{c}\text { SPARC } \\
(\%)\end{array}$ & $\begin{array}{c}\text { SOX1 } \\
(\%)\end{array}$ & $\begin{array}{c}\text { DBC1 } \\
(\%)\end{array}$ & $\begin{array}{c}\text { TWIST1 } \\
(\%)\end{array}$ & $\begin{array}{c}\text { SCGB3A1 } \\
(\%)\end{array}$ & $\begin{array}{c}\text { THY1 } \\
(\%)\end{array}$ \\
\hline Serous (n=10) & $7(70)$ & $3(30)$ & $4(40)$ & $1(10)$ & $0(0)$ & $1(10)$ & $1(10)$ \\
Mucinous (n=10) & $5(50)$ & $2(20)$ & $3(30)$ & $4(40)$ & $2(20)$ & $0(0)$ & $1(10)$ \\
Endometrioid (n=10) & $4(40)$ & $3(30)$ & $1(10)$ & $1(10)$ & $0(0)$ & $0(0)$ & $0(0)$ \\
Clear cell $(\mathrm{n}=10)$ & $6(60)$ & $3(30)$ & $4(40)$ & $2(20)$ & $0(0)$ & $4(40)$ & $3(30)$ \\
Total $(\mathrm{n}=40)$ & $22(55)$ & $11(27.5)$ & $12(30)$ & $8(20)$ & $2(5)$ & $5(12.5)$ & $5(12.5)$ \\
\hline
\end{tabular}


methylation at high frequency, and methylation of the TWIST1 promoter is a good predictor of human breast cancer (38). DBC1 and TWIST1 were hypermethylated predominantly in ovarian mucinous adenocarcinoma in this study, and therefore potentially a candidate marker of this OEC subtype.

This study has elucidated the importance of epigenetic regulation in the development of different OEC subtypes. We identified several epigenetically dysregulated gene targets in OEC through global screening, using a microarray-based assay and a subsequent validation method.

\section{Acknowledgements}

This work was supported by a grant of Medical Research Institute, Pusan National University, Busan, Republic of Korea (20080031000), and by a grant from the National R\&D Program for Cancer Control, Ministry for Health, Welfare and Family Affairs, Republic of Korea (0920050).

\section{References}

1. Jemal A, Murray T, Ward E, Samuels A, Tiwari RC, Ghafoor A Feuer EJ and Thun MJ: Cancer statistics, 2005. CA Cancer J Clin 55: 10-30, 2005.

2. Ibanez de Caceres I, Battagli C, Esteller M, Herman JG, Dulaimi E, Edelson MI, Bergman C, Ehya H, Eisenberg BL and Cairns P: Tumor cell-specific BRCA1 and RASSF1A hypermethylation in serum, plasma and peritoneal fluid from ovarian cancer patients. Cancer Res 64: 6476-6481, 2004.

3. Khouja MH, Baekelandt M, Nesland JM and Holm R: The clinical importance of ki-67, p16, p14 and p57 expression in patients with advanced ovarian carcinoma. Int J Gynecol Pathol 26: 418-425, 2007

4. Esteller M, Corn PG, Baylin SB and Herman JG: A gene hypermethylation profile of human cancer. Cancer Res 61: 3225-3229, 2001 .

5. Al-Kuraya K, Narayanappa R, Siraj AK, Al-Dayel F, Ezzat A, El Solh H, Al-Jommah N, Sauter G and Simon R: High frequency and strong prognostic relevance of O6-methylguanine DNA methyltransferase silencing in diffuse large B-cell lymphomas from the middle east. Hum Pathol 37: 742-748, 2006.

6. Chu LC, Eberhart CG, Grossman SA and Herman JG: Epigenetic silencing of multiple genes in primary CNS lymphoma. Int J Cancer 119: 2487-2491, 2006.

7. Gu J, Berman D, Lu C, Wistuba II, Roth JA, Frazier M, Spitz MR and $\mathrm{Wu} \mathrm{X}$ : Aberrant promoter methylation profile and association with survival in patients with non-small cell lung cancer Clin Cancer Res 12: 7329-7338, 2006

8. Yang HJ, Liu VW, Wang Y, Tsang PC and Ngan HY: Differential DNA methylation profiles in gynecological cancers and correlation with clinico-pathological data. BMC Cancer 6: 212, 2006.

9. Wiley A, Katsaros D, Chen H, Rigault de la Longrais IA, Beeghly A, Puopolo M, Singal R, Zhang Y, Amoako A, Zelterman D and $\mathrm{Yu} \mathrm{H}$ : Aberrant promoter methylation of multiple genes in malignant ovarian tumors and in ovarian tumors with low malignant potential. Cancer 107: 299-308, 2006.

10. Katsaros D, Cho W, Singal R, Fracchioli S, Rigault de la Longrais IA, Arisio R, Massobrio M, Smith M, Zheng W, Glass $\mathrm{J}$ and $\mathrm{Yu} \mathrm{H}$ : Methylation of tumor suppressor gene p16 and prognosis of epithelial ovarian cancer. Gynecol Oncol 94: 685-692, 2004.

11. Makarla PB, Saboorian MH, Ashfaq R, Toyooka KO, Toyooka S, Minna JD, Gazdar AF and Schorge JO: Promoter hypermethylation profile of ovarian epithelial neoplasms. Clin Cancer Res 11: 5365-5369, 2005.

12. Rathi A, Virmani AK, Schorge JO, Elias KJ, Maruyama R, Minna JD, Mok SC, Girard L, Fishman DA and Gazdar AF: Methylation profiles of sporadic ovarian tumors and nonmalignant ovaries from high-risk women. Clin Cancer Res 8 : 3324-3331, 2002.
13. Strathdee G, Appleton K, Illand M, Millan DW, Sargent J, Paul J and Brown R: Primary ovarian carcinomas display multiple methylator phenotypes involving known tumor suppressor genes. Am J Pathol 158: 1121-1127, 2001.

14. Teodoridis JM, Hall J, Marsh S, Kannall HD, Smyth C, Curto J, Siddiqui N, Gabra H, McLeod HL, Strathdee G and Brown R: $\mathrm{CpG}$ island methylation of DNA damage response genes in advanced ovarian cancer. Cancer Res 65: 8961-8967, 2005.

15. Huang YW, Jansen RA, Fabbri E, Potter D, Liyanarachchi S, Chan MW, Liu JC, Crijns AP, Brown R, Nephew KP, van der Zee AG, Cohn DE, Yan PS, Huang TH and Lin HJ: Identification of candidate epigenetic biomarkers for ovarian cancer detection. Oncol Rep 22: 853-861, 2009.

16. Santin AD, Zhan F, Cane' S, Bellone S, Palmieri M, Thomas M, Burnett A, Roman JJ, Cannon MJ, Shaughnessy J Jr and Pecorelli S: Gene expression fingerprint of uterine serous papillary carcinoma: identification of novel molecular markers for uterine serous cancer diagnosis and therapy. Br J Cancer 92: 1561-1573, 2005

17. Wei SH, Chen CM, Strathdee G, Harnsomburana J, Shyu CR, Rahmatpanah F, Shi H, Ng SW, Yan PS, Nephew KP, Brown R and Huang TH: Methylation microarray analysis of late-stage ovarian carcinomas distinguishes progression-free survival in patients and identifies candidate epigenetic markers. Clin Cancer Res 8: 2246-2252, 2002.

18. Bibikova M, Lin Z, Zhou L, Chudin E, Garcia EW, Wu B, Doucet D, Thomas NJ, Wang Y, Vollmer E, Goldmann T, Seifart C, Jiang W, Barker DL, Chee MS, Floros J and Fan JB: High-throughput DNA methylation profiling using universal bead arrays. Genome Res 16: 383-393, 2006.

19. Wu Q, Lothe RA, Ahlquist T, Silins I, Tropé CG, Micci F, Nesland JM, Suo Z and Lind GE: DNA methylation profiling of ovarian carcinomas and their in vitro models identifies HOXA9, HOXB5, SCGB3A1 and CRABP1 as novel targets. Mol Cancer 6: 45,2007

20. Fiegl H, Windbichler G, Mueller-Holzner E, Goebel G, Lechner M, Jacobs IJ and Widschwendter M: HOXA11 DNA methylation - a novel prognostic biomarker in ovarian cancer. Int J Cancer 123: 725-729, 2008.

21. Cheng P, Schmutte C, Cofer KF, Felix JC, Yu MC and Dubeau L: Alterations in DNA methylation are early, but not initial, events in ovarian tumorigenesis. Br J Cancer 75: 396-402, 1997.

22. Choi YL, Kang SY, Choi JS, Kim SH, Lee SJ, Bae DS and Ahn G: Aberrant hypermethylation of RASSF1A promoter in ovarian borderline tumors and carcinomas. Virchows Arch 448: 331-336, 2006.

23. Porte H, Chastre E, Prevot S, Nordlinger B, Empereur S, Basset P, Chambon P and Gespach C: Neoplastic progression of human colorectal cancer is associated with overexpression of the stromelysin-3 and BM-40/SPARC genes. Int J Cancer 64: 70-75, 1995.

24. Le Bail B, Faouzi S, Boussarie L, Guirouilh J, Blanc JF, Carles J, Bioulac-Sage P, Balabaud C, Rosenbaum J: Osteonectin/SPARC is overexpressed in human hepatocellular carcinoma. J Pathol 189: 46-52, 1999

25. Yang E, Kang HJ, Koh KH, Rhee H, Kim NK and Kim H: Frequent inactivation of SPARC by promoter hypermethylation in colon cancers. Int J Cancer 121: 567-575, 2007.

26. Yiu GK, Chan WY, Ng SW, Chan PS, Cheung KK, Berkowitz RS and Mok SC: SPARC (secreted protein acidic and rich in cysteine) induces apoptosis in ovarian cancer cells. Am J Pathol 159: 609-622, 2001.

27. Krop I, Parker MT, Bloushtain-Qimron N, Porter D, Gelman R, Sasaki H, Maurer M, Terry MB, Parsons R and Polyak K: HIN-1, an inhibitor of cell growth, invasion and AKT activation. Cancer Res 65: 9659-9669, 2005.

28. Shigematsu H, Suzuki M, Takahashi T, Miyajima K, Toyooka S, Shivapurkar N, Tomlinson GE, Mastrangelo D, Pass HI, Brambilla E, Sathyanarayana UG, Czerniak B, Fujisawa T, Shimizu N and Gazdar AF: Aberrant methylation of HIN-1 (high in normal-1) is a frequent event in many human malignancies. Int J Cancer 113: 600-604, 2005.

29. Fukuda H, Takahashi J, Watanabe K, Hayashi H, Morizane A, Koyanagi M, Sasai Y and Hashimoto N: Fluorescence-activated cell sorting-based purification of embryonic stem cell-derived neural precursors averts tumor formation after transplantation. Stem Cells 24: 763-771, 2006

30. Lai HC, Lin YW, Huang TH, Yan P, Huang RL, Wang HC, Liu J, Chan MW, Chu TY, Sun CA, Chang CC and Yu MH: Identification of novel DNA methylation markers in cervical cancer. Int J Cancer 123: 161-167, 2008. 
31. Crawford JM and Barton RW: Thy-1 glycoprotein: structure, distribution and ontogeny. Lab Invest 54: 122-135, 1986.

32. Abeysinghe HR, Pollock SJ, Guckert NL, Veyberman Y, Keng P, Halterman M, Federoff HJ, Rosenblatt JP and Wang N: The role of the THY1 gene in human ovarian cancer suppression based on transfection studies. Cancer Genet Cytogenet 149: 1-10, 2004.

33. Lung HL, Bangarusamy DK, Xie D, Cheung AK, Cheng Y, Kumaran MK, Miller L, Liu ET, Guan XY, Sham JS, Fang Y, Li L, Wang N, Protopopov AI, Zabarovsky ER, Tsao SW, Stanbridge EJ and Lung ML: THY1 is a candidate tumour suppressor gene with decreased expression in metastatic nasopharyngeal carcinoma. Oncogene 24: 6525-6532, 2005

34. Habuchi T, Luscombe M, Elder PA and Knowles MA: Structure and methylation-based silencing of a gene (DBCCR1) within a candidate bladder cancer tumor suppressor region at 9q32-q33. Genomics 48: 277-288, 1998 .
35. Gao S, Worm J, Guldberg P, Eiberg H, Krogdahl A, Sørensen JA, Liu CJ, Reibel J and Dabelsteen E: Loss of heterozygosity at $9 q 33$ and hypermethylation of the DBCCR1 gene in oral squamous cell carcinoma. Br J Cancer 91: 760-764, 2004.

36. Izumi H, Inoue J, Yokoi S, Hosoda H, Shibata T, Sunamori M, Hirohashi S, Inazawa J and Imoto I: Frequent silencing of $\mathrm{DBC} 1$ is by genetic or epigenetic mechanisms in non-small cell lung cancers. Hum Mol Genet 14: 997-1007, 2005.

37. Maestro R, Dei Tos AP, Hamamori Y, Krasnokutsky S, Sartorelli V, Kedes L, Doglioni C, Beach DH and Hannon GJ: Twist is a potential oncogene that inhibits apoptosis. Genes Dev 13: 2207-2217, 1999

38. Fackler MJ, McVeigh M, Mehrotra J, Blum MA, Lange J, Lapides A, Garrett E, Argani P and Sukumar S: Quantitative multiplex methylation-specific PCR assay for the detection of promoter hypermethylation in multiple genes in breast cancer. Cancer Res 64: 4442-4452, 2004. 